\title{
Sosyal Sermayenin Motivasyon ve İş Tatmini Arasındaki Aracılık Etkisi: Batman Üniversitesi Örneği
}

\author{
Muhammed Mahsun ŞAHIN * $\quad$ Osman YILMAZ **
}

\begin{abstract}
$\ddot{O} Z$
Bu çalışmada Batman Üniversitesi çalışanları üzerinde yapılan araştırma ile sosyal sermayenin motivasyon ve iş tatmini arasında aracılık etkisi araştırılmıştır. Bu nedenle 286 akademik ve idari personele dört bölümden oluşan sorular sorulmuştur. Çalışma ölçeğinin ilk bölümünde kişisel bilgiler, ikinci bölümünde 29 sorudan oluşan motivasyon ölçeği, üçüncü bölümünde 20 sorudan oluşan Minnesota iş tatmin ölçeği, ölçeğin son bölümünde 8 sorudan oluşan sosyal sermaye ölçeği oluşturmaktadır. Veriler SPSS analiz programı aracılığlyla istatiksel metotlarla analiz edilmiştir. Yapılan analizler sonucunda, sosyal sermayenin motivasyon ve iş tatmini arasında kısmi ara değişken etkisine sahip olduğu tespit edilmiştir.
\end{abstract}

Anahtar Kelimeler: Sosyal Sermaye, İ̧̧ Tatmini, Motivasyon.

JEL Sinuflandirmast: $M 0, M 1$, M10

\section{The Mediation Effect of Social Between Motivation and Job Satisfaction: The Case of Batman University}

\begin{abstract}
In this study, the mediating effect of social capital between motivation and job satisfaction was investigated with the research conducted on Batman University employees. For this reason, fourpart questions were asked to 286 academic and administrative staff. Personal information in the first part of the study scale, Motivation scale with 29 questions in the second part, Minnesota Job Satisfaction scale with 20 questions in the third part, and Social Capital scale consisting of 8 questions in the last part of the scale. The data were analyzed by statistical methods using the SPSS analysis program. As a result of the analysis, it has been determined that social capital has a partial moderator effect between motivation and job satisfaction.
\end{abstract}

Key Words: Social Capital, Job Statisfaction, Motivation.

JEL Classification: M0, M1, M10

\section{GíRIŞ}

Sosyal bir varlık olarak insanın, iş hayatında yaşadığı olumlu veya olumsuz etkileşim iş verimliliğini etkilemektedir. $\mathrm{Bu}$ nedenle örgütlerin birbirleriyle kıyasıya rekabet halinde olduğu çağımızda iş görenlerin iş tatmini ve motivasyonunu yüksek tutmak örgütlerin geleceği için elzem hale gelmiştir. Gelişmiş toplumların insan ilişkileri güvene dayalıdır, insanların birbirleriyle iletişim içinde olmaları kişiler arasında karşılıklı güveni pekiştirir, örgütlü hareket etme imkanını sağlar ve daha bilinçli adımlar atmasına olanak vererek ortak

\footnotetext{
*Batman Üniversitesi, Strateji Dairesi, mas.mahsum@gmail.com, ORCID Bilgisi: 0000-0003-4472-9053

** Dr. Öğr. Üyesi, Batman Üniversitesi, İ̈BF İşletme Bölümü, osmnylmz@hotmail.com, ORCID Bilgisi: 0000-0001-7512-5076
} 
hedeflere odaklanma imkanı yaratır. Bu unsurların insan ilişkilerinde yarattığ bağlanma duygusu toplumda grup aidiyeti kimliği kazandırır.

Yükseköğretim kurumları toplumun en önemli modelleridir. Yönetici ve işgörenlerin iletişim halinde olmadığı, kurumda aidiyet duygusunun pekişmediği, çalışanların birbirlerine güvenmediği ve çalıştığ1 işten mutsuz işgörenlerin çoğunlukta olduğu üniversiteler ne topluma model olur nede diğer yükseköğretim kurumlarıyla rekabet edebilir (Durkan Şimşek, 2013).

Bilimsel bilginin üretildiği yükseköğretim kurumlarında çalışan işgörenlerin değeri kurumun sahip olduğu maddi kıymetten daha yüksektir. Bu konunun önemine binaen yükseköğretim kurumlarında sosyal sermayenin motivasyon ve iş tatmini arasındaki aracılık etkisini incelemenin önemli olacağ1 düşünülmektedir.

\section{SOSYAL SERMAYE}

Ekonomi, siyaset ve toplum modellerinin karşı karşıya kaldığı krizler, sosyal bilimlerde yeni kavramların doğuşuna neden olmuşlardır. "Sosyal sermaye" insan ilişkilerinde var olan iktisadi, siyasi ve insanlar arası ilişkileri açıklamaya, anlamaya, yönlendirmeye ve çözüm üretmeye dönük farklı disiplinlerin katkısı ile var olan sorunların tespiti ve çözümü anlamında popülerlik kazanmış bir kavramdir.

Fransız düşünür Tocqueville sosyal sermaye kavramını içerdiği anlama göre ilk kullanan isimdir. Ünlü düşünür direkt olarak sosyal sermaye kavramını kullanmamış fakat sosyal sermaye kavramına ilerleyen süreçte verilecek değerin altını çizmiştir. Tocqueville, Amerikan ekonomik gücünün ve demokrasisinin temel dayanağı olan coşkulu toplumsal yaşamı alışık olduğu şekliyle daha hiyerarşik ve geleneksel ilişkileri yan yana tutan yükümlülük ve resmi statü bağlarının tersine gönüllü kuruluşlardaki etkileşimin bireysel Amerikalıların birbirine bağlayıcı özelliği olduğunu savunmuştur. Amerikan toplumunda Fransa'nın aksine demokratik cumhuriyetin yaşatılmasında, ülkenin fiziksel koşullarından daha çok kanunların ve kanunların önünde de törelerin bulunduğunu belirtmektedir. Ayrıca Tocqueville insanların birbirlerinin çıkarlarına ve haklarına duydukları sayg1 ile bütün milletin bu saygıyı göstereceğine duyulan güvenin sosyal sermayeyi öne çıkaran en önemli unsur olduğuna işaret etmektedir (Tocqueville, 1994).

Sosyal sermayeye yönelik yapılan tanımlarda, işbirliği, iletişim ağları, güven, dayanışma, kolektif eylem ve gönüllü kuruluşlar gibi kavramların yer aldığı görülmektedir. İşte bu kavramların birbirleriyle olan ilişki oranları, sosyal sermayenin ortaya çıkmasındaki ana unsurlar olarak araştırmaların kaynağını oluşturmaktadırlar. Bu kaynaklar doğrultusunda sosyal sermaye; "insanların ortak amaçlart için bireyler, gruplar ya da organizasyonlar halinde bir arada çalışma yetene ğidir" şeklinde tanımlanmaktadır (Ören, 2007).

Genel itibariyle sosyal sermaye "toplumsal eylemin gerçekleştirilmesinde gerekli olan sosyal yapılar ve ağlar; bu yapılar içinde normatif içerikler (güvenirlilik ve karşılıklı ilişkiler) ve bununla birlikte yapılar aracılığıyla elde edilen kolektif eylemlerin sonuçları” anlamına gelir (Prakash ve Selle, 2004). 
Ekonomik alanda sosyal sermayenin önemli getirileri bulunmaktadır. $\mathrm{Bu}$ anlamda Çetin, (2006, s.75) sosyal sermayenin iktisadi açısından önemi hakkında şu şekilde düşünmektedir:

Birincisi olarak sosyal sermaye, kolektif faaliyetlerin artmasını sağlayarak, bireylere topluca hareket etme gönüllülüğü ve arzusu verir. Sosyal faktörlerin bu etkileri sonucunda sosyal sermaye birikimi, örgütlerin amaçlarını gerçekleştirmelerinde olumlu etkiye sahip olacaktır. Sosyal sermaye, iş birliğinin ve sinerjinin ana eksenini oluşturmaktadır ayrıca sosyal kurumlar, toplumsal ilişkileri ve bu kurumlar arasında oluşabilecek birlikteliğin boyutunu ve yapısını belirlemek, sosyal ilişkilere bağlı kurumsal çalışmaları etkilemektedir.

Sosyal sermayenin etkilediği alanlardan birisi de eğitim sektörüdür. Coleman, öğrenciler üzerinde yapmış olduğu bir araştırmada eğitim, sosyoekonomik ve kültürel bakımından iyi durumdaki ailelerinin çocukları, şartları daha elverişsiz durumdaki ailelerinin çocuklarına göre daha başarılı olduğu görülmüştür. Sosyal sermayesi yüksek olan toplumların eğitim seviyesi ve beşeri sermayesi de daha yüksektir (Field, 2008).

Sosyal sermayenin toplum açısından önemine baktığımızda ise sosyal sermaye düzeyi yüksek toplumlardaki insanlar arasındaki ilişkilerin daha samimi, kamu alanlarının daha temiz ve sokaklarının daha güvenli bir nitelik taşıdığ görülmektedir. Nitekim sosyal sermayesi düşük olan toplumlarda ise aksine suç oranlarının daha fazla olduğu ve risk faktörlerinin daha yoğunlukta olduğu tespit edilmektedir. $\mathrm{Bu}$ durumun nedeni toplumsal eğitim seviyesinin düşüklüğü, bireylerin toplumsal organizasyonlara katılmada çekingenlik göstermesi ile gençleri sınırlandıracak toplumsal normlar, değerler ve bu değerlerin nitelikli bir şekilde gelişmesini sağlayacak arkadaşlık ilişkileri ve toplumsal yapılanmasının bulunmadığı görülmektedir (Putnam, 2000).

\section{II. İŞ TATMINI}

İş tatmini, iş görenin gerçekleştirdiği işten, iş yerinden, çalışma nizamından, iş arkadaşlarından, idarecilerinden, eline geçen ücretten memnuniyeti şeklinde de tanımlanmaktadır. Tatmin kavramı; arzu edilen bir şeyin elde edilmesi, bireyin iç dünyasında doyuma ulaşma olarak ifade edilmektedir. Gereksinimlerin elde edilmesi sonucu ortaya çıkan mutluluk hali olarak da tanımlanmaktadır. İnsanoğlu tabiatının bir gereği olarak sürekli maddi ve manevi gereksinimlerini giderme çabası içinde yaşamaktadır. Birey çabalarının karşılığı olarak beklentilerini elde ettiğinde bir tatmin duygusu yaşamaktadır (Karcıŏlu, Timuroğlu ve Çınar, 2009).

İş görenler, zamanlarının büyük bir çoğunluğunu çalıştıkları ortamlarda geçirmektedirler. Bu yüzden işinde tatmin olmayan bireylerin hayatları olumsuz etkilenmektedir. Yapılan işin mecburiyetten ziyade severek gerçekleştirilmesi, iş tatmininin oluşmasında büyük bir etkiye sahiptir. Firmalar, hedeflerine erişmek için sağlıklı işgücüne gereksinim duymaktadırlar. Çalışanların fiziksel ve psikolojik durumları, yönetim biliminde, örgüt içi etkinliğin sağlanması ve performansın yükseltilmesi bakımından üzerinde dikkatle durulması gereken hususların başında yer almaktadır. İşinde tatmine ulaşmış sağlıklı çalışanlardan daha yüksek oranda 
verim ve performans artışları görülmektedir. Bunun yanında tatmin olmama durumu çalışanların psikolojik sağlıklarını olumsuz etkilemektedir. $\mathrm{Bu}$ durum çalışanın veriminde ve performansında düşüşe neden olmaktadır. Bireylerin iş ortamındaki huzuru veya huzursuzluğu hem işlerine hem de özel yaşamlarına yansıyabilir (Yazıcıŏ̆lu, 2010).

Herzberg ve arkadaşları 1950'li yılların sonunda 1960'lı yılların başlarında iki faktör kuramını geliştirmiştir. Herzberg kuramında, iş tatmini ve verimlilik arasındaki bağ ile yakından ilgilenmiş (Baysal ve Tekarslan, 1996), yapılan işin kendisi ile alakalı etkenlerin; iş doyumu ve yükselen verimlilik üzerinde olumlu etkileri olduğunu ifade etmiştir (Hodgetts, 1999). Herzberg, yapılan işin kendisi ile alakalı olan ve iş görenleri tatmin eden etkenleri "motive edici faktörler", işin çalışma şartları ile alakalı olan etkenleri de "hijyen faktörler" olarak adlandırmıştır.

İş görenlerin iş tatmin seviyesine etki eden pek çok etken bulunsa da literatürde bireysel ve örgütsel etkenler olmak üzere iki başlik altında toplanmaktadır (Sabuncuoğlu ve Tüz, 2005). Bireysel etkenler, kişilerin değişik seviyede tatmin olmalarını sağlayan faktörlerdir. Örgütsel etkenler ise işin kendisi, idare şekli ve kontrol biçimi, güvenlik algısı, iletişim, ücret, ilerleme ve terfi imkân olanakları, rekabet, çalışma koşulları, iş arkadaşları ve örgütsel iklim şeklinde siniflandirılmaktadir (Akınc1, 2002).

İş tatmininin dışsal etkenlerinin oluşmasını sağlayan değişkenler; işyeri şartları (1sıtma, havalandırma vb.), alınan ücret, işyerinin sunduğu olanaklar (yemek sigorta vb.), yükselme ve başarıya bağlı ücret artışı şeklinde belirtilmektedir. Özdemir'in (2006) örgütsel iklim ve iş tatmini arasındaki bağ1 araştıran çalışmasında iş doyumu ile alakalı gerçekleştirilen etken analizinin neticeleri, Herzberg'in (1974) çift faktör kuramını destekleyen özellikler barındırmaktadır. Çift faktör kuramına göre; iş tatmini, içsel ve dişsal etkenler olarak tanımlanmış, bu etkenlerden "Motive Edici Faktörler', içsel faktörleri ifade etmekte, "Hijyen Faktörler"' ise dişsal faktörleri ifade etmektedir. İş tatminini etkileyen içsel faktörler, işin kendisi, mesuliyet, terfi, bireyin şirket içindeki yeri, başarı ve tanınmadır. Bu etkenlerin var olması bireyi motive etmektedir. iş tatminini etkileyen dışsal etkenler ise, ücret, iş ortamındaki çalışma şartları, iş emniyeti gibi etkenlerdir. Bu etkenlerin bireyi güdüleme özelliği bulunmamaktadır. $\mathrm{Bu}$ etkenler, tatminsizliğe neden olmaktadır (Gül, Ercan ve Gökçe, 2008).

İş tatmininin içsel etkenleri; ekip olarak çalışmak, iş ortamında kurulan dostluk ve arkadaşlıklar, iş görenlerin görev, yetki ve mesuliyetleri, bireyin kabiliyet ve becerilerini sergileyebilme imkânı, idarecilerin yetkinliği, çalışma süresi ve bu saatlerin çalışana uygunluğu, çalışanın firmaya verdiği değer olarak sıralanmaktadır (Gül, Ercan ve Gökçe, 2008).

Özmen, Aküzüm, Koçoğlu, Tan ve Demirkol (2014) tarafından yapılan araştırmalarda sosyal sermayenin iş tatminini anlamlı olarak etkilediği ve açıkladığını göstermektedir.

Akan ve Er Ülker (2015), Yaptıkları çalışma sonucunda, sosyal sermaye ve iş tatmini değişkenleri arasında anlamlı bir ilişki olduğunu ayrıca akademik 
personelin iş tatmini düzeyleri, sosyal sermaye düzeyinden olumlu yönde etkilendiği sonucuna ulaşılmıştır.

Araştırmaların sonuçlarına göre örgütsel bağ l1lığın, performans, stres, işten ayrılma, personel devri ve iş tatmini ile aralarında ciddi bağlantılar bulunduğu belirlenmiştir (Clugston, Howell, ve Dorfman 2000).

Yang ve Chang (2008), sağllk sektöründe çalışan hemşireler üzerindeki bir araştırmasında, iş tatmini ile örgütsel bağ lılığın bağlantılı olduğunu saptamıştır.

Ingersoll (2012), hemşirelerin örgütsel bağlılıkları ile iş tatminleri arasında güçlü bir bağlantı olduğunu belirlemişlerdir.

Jahangir ve Shokrpour (2009), hemşireler üzerinde uyguladığ çalışmada, "duygusal bağlllık" ve "normatif bağlllı̆̆ın iş tatmini ile aralarında olumlu bir bağlantının bulunduğunu, "devamlılık bağglılığının" ise iş tatmini ile aralarında olumsuz bir bağlantının bulunduğunu saptamışlardır.

Lee ve Tan (2010), sağlık personellerinin normatif ve duygusal bağlılı̆̆ının iş tatminini olumlu etkilediğini, buna rağmen devamlılık bağlılı̆̆ının iş tatmini üzerinde anlamlı bir etkisinin bulunmadığını belirlemişlerdir.

Sağlık sektöründe yürütülen çalışmalarda olduğu gibi farklı sektörlerde gerçekleştirilen çalışmalarda da aynı sonuçlara rastlanılmaktadır.

Özdemir (2008), çalışmasında bireylerin sosyal bağlantıları ve işletme işgörenler arasındaki yakın ilişkiler iş tatmini düzeyini etkilediği tespit edilmiştir. Sosyal sermaye çok geniş boyutlardan oluştuğundan bazı çalışmalarda iş tatmini ve sosyal sermaye ilişki durumu kuvvetli iken bazı çalışmalarda zayıf bir ilişki durumu tespit edilmiştir.

\section{MOTIVASYON}

Günlük iş hayatında siklıkla kullanılan motivasyon ifadesi, en basit tanımıyla; arzu edilen bir davranışı başlatma, tevcih etme ve devam ettirme hareketi olarak ifade edilmektedir. Motivasyon ifadesinin birçok tarifini bulmak mümkündür. Bunlardan en genel olanı "belirli bir amaç için kişiyi harekete geçiren, çalışmaya teşvik eden, başarlyı hedefleyen ve kişinin kendi içinde hissettiği güçtür" ş̧eklinde tanımlamak mümkündür (Düren, 2002).

Günümüz iş hayatında çalışanları motive etmek ve özendirmek zor ve karmakarışık bir süreçtir. Bunun en büyük nedeni ise insanoğlunun arzularının karmaşık ve uçsuz bucaksız olmasıdır. İnsanların bu gereksinimleri bireysel değişiklikler göstermesi de bir diğer zorunluluk halini teşkil eder. Tüm bu hususlar motivasyonun önemli olması kadar güç olduğunu da açıklamaktadır.

Motivasyon teorileri çalı̧̧anlardaki motivasyonu yükseltmek için; bireyi harekete sevk eden nedir? Bireyi iki davranıştan birini seçmesine yol açan nedir? Bireyleri aynı motivasyonel uyaranlara aynı davranışı vermezler (Aksoy, Koancı ve Namal, 2019). İşgörenin öncelik verdiği ihtiyacın yönetici tarafından bilinmesi, işgörenin seçiminden yapılacak terfilere kadar, belirlenecek hedeften yapılacak performans değerlendirmesine kadar iş görenlerle ilgili her türlü veri, işverenin yararına olacaktır. Çünkü ihtiyacı giderilen çalışan bireysel ve hedefleri ile örgüt hedefleri arasında bir ortak nokta üzerinden yüksek derecede performans gösterebilir (Eryılmaz ve Altın Gülova, 2019). 
Örgütlerde amaç, bütün kaynakların aktif ve yüksek düzeyde kullanılmasını sağlamaktır. Eldeki kaynakların sonsuz olmaması, savurganlığ1 önlemeyi gerektirmektedir. Ekonominin etkinlik ve gerçeklik ilkeleri gereğince kaynak israfının önüne geçmek ve örgütsel gayeye kavuşmak gerekmektedir. Yönetimdeki kişilerin motivasyon ile alakalı çalışmalar yapması çok önemlidir çünkü; başarı, takımın örgütsel gayeleri gerçekleştirecek yönde çalışmalarına; güç, beceri ve bilgilerini bu yönde sarf etmelerine bağl1 olarak mecburiyet söz konusudur. Bunların oluşmasının ise tek yolu motivasyonun sağlanmasıyla mümkündür (Koçel, 2018).

Maslow'un ihtiyaç teorisi hiyerarşi, motivasyonun en temel teorilerinden biridir. Bilindiği gibi Maslow, insan ihtiyaçlarını beş gruba ayırdı. Temel ihtiyaçlar güvenlik ve sonra psikolojik olarak listelenmiştir (ait olmak, saygı duymak ve kendini gerçekleştirme) (Doğan ve Arslan, 2018).

Bahsedilen bu kuramın iki temel öncülü vardır. (Armstrong, 2003):

a) Gereksinimler elde edilip tatmin edildiklerinde motive etme özelliklerini yitirmektedir. Tatmin edilmeyen gereksinimler motive edici özelliklerini korumaktadırlar. Bir ihtiyaç tatmin edildiğinde diğer bir ihtiyaç meydana çıkmaktadır.

b) Tatmin edilen bir ihtiyaçtan sonra bir başka ihtiyaç ortaya çıkmaktadır. David C. McClelland tarafindan geliştirilen başarma ihtiyacı kuramı, 1938 yılında Henry A. Murray'ın ortaya atmış olduğu ve insan davranışlarının sebebini meydana getirdiğini belirttiği yirminin üzerinde bir dizi ihtiyaçtan sadece başarı, yakın ilişki ve güç ihtiyaçlarını içermekte olan bir kuramdır. McClelland söz konusu üç ihtiyaçtan genellikle başarı ihtiyacı üzerinde yoğun şekilde çalışmış olsa da pek çok çalışmasında bu üç ihtiyacı birlikte test etmiştir (Çelik, 2010).

Motivasyon kuramlarından bir diğeri de süreç kuramlarıdır. Süreç kuramları, bireyin bilişsel özelliklerinin motivasyon sürecindeki etkisine değinmektedir. Bu kuramlara göre, motivasyonu geliştirmek için çevresel faktörler yeterli değildir. Kişinin çevresel değişkenler ile alakalı değerlendirmeleri bu süreçte büyük bir rol oynamaktadır. Amaçlara çaba sonucunda ulaşabileceğine inanmak, elde edileceklere değer vermek ve daha ileriye gitmek için bunları kullanabileceğini düşünmek kişiye motivasyon sağlamaktadır. Çevredeki olumsuzluklar ve eksiklikler ile alakalı değerlendirmeler, bunların kişiyi engellemesine izin verme durumuna bağlıdır. Süreç kuramları kişinin kendi kendisini motive edebilme düşüncesini ortaya koyan kuramlardır (Güney, 2001).

\section{YÖNTEM}

\section{A. Araștırmanın Amacı}

$\mathrm{Bu}$ çalışmada; Batman Üniversitesinde çalışan akademik ve idari personelin, sosyal sermaye, motivasyon ve iş tatmini arasındaki aracıllk etkisinin tespitini yapmak.

\section{B.Evren ve Örneklem}

Çalışmanın evreni Batman Üniversitesinde çalışan 901 personel oluşturmaktadır. Üniversite Etik Kurulundan gerekli izin alındıktan sonra 300 anket formu elden dağıtılmıştır. Ayrıca 750 personele e-posta aracılığıyla online anket 
formu gönderilmiştir. İki hafta süren anket çalışması sonucunda 286 anket bilgisi değerlendirmeye alınmıştır. Anket formu 5-li likert ölçeği ile ölçeklendirilmiştir.

$$
n=\frac{N * t^{2} * p * q}{d^{2} *(N-1)+t^{2} * p * q}
$$

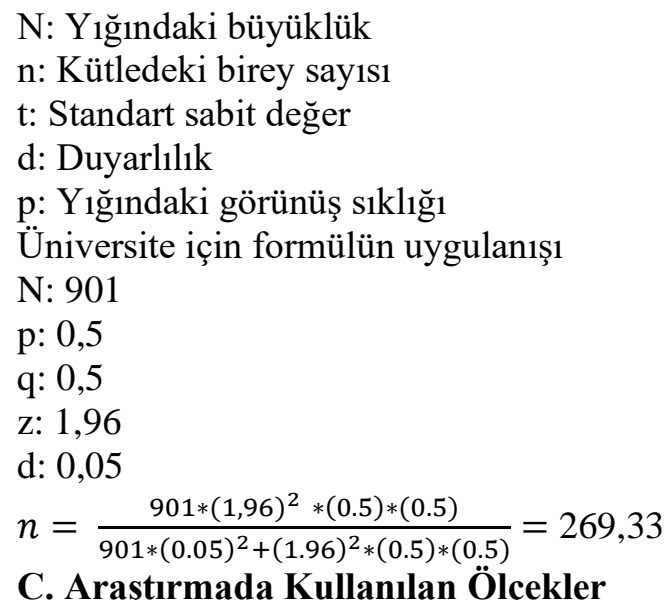

Sosyal sermaye ölçeği örgütlerde geçerliği ve psiko-metrikliği onaylanmış bir ölçektir. Ölçek, sosyal sermayenin hem bilişsel ve yapısal kısımlarını barındırmakta hem de bir birleriyle anlam bütünlüğüne değinmektedir. Ölçek bir örgütteki iş görenlerin ortak tutumları, karşılıklı saygı ve güveni, çalışanların iletişim ağlarındaki birlikteliği ve katılım ile amirlerin saygınlığını belirlemektedir (Kouvonen vd., 2008). Ölçekteki 8 soru Türkçe' ye dil uzmanlarınca çevrilmiş ve olası çeviri problemleri ve kültürel farklılıklardan kaynaklı hataları engellemek için geri tercüme prosedürü uygulanmıştır. Uzman görüşleri doğrultusunda düzenlemeler yapılarak ölçeğin son hali oluşturulmuştur.

Ölçeğin yapı geçerliliğine ilişkin bulgular açıklayıcı faktör analizi yöntemi ile sağlanmıştır. Ölçek maddeleri iki faktöre ayrılmıştır. Ölçeğe uygulanan faktör analizi sonucunda geçersiz olduğu belirlenen bir ifade (Amirlerimize güvenebiliriz.) analizden çıkarılmıştır. Son durumda ise ölçek toplamda 7 ifadeye indirgenmiştir. Ölçeğin içsel tutarlı̆̆ını belirlemek için Cronbach's Alpha katsayısı hesaplanmıştır. Buna göre ölçeğin yüksek düzeyde $(0,898)$ iç tutarlılığa sahip olduğu tespit edilmiştir.

Motivasyon ölçeği: Ölçek, Mottaz (1985), Brislin, Kabigting, Macnab, Zukis ve Worthley (2005), Mahaney ve Lederer (2006)'in çalışmalarında kullandıkları, motivasyon boyutlarından oluşan 24 maddeli bir ölçek temel alınarak, Dündar, Özutku, ve Taşpınar, F. (2007) tarafından geliştirilmiş ve 29 soruluk ölçeğe dönüştürülmüş olan ölçek kullanılmıştır.

İş tatmini ölçeği, akademik araştırmalarda çalışanların iş doyumlarını ölçmek için en fazla tercih edilen Minnesota iş tatmin ölçeğidir. Ölçek, 1967 yılında Weiss, Dawis, England ve Lofquist tarafından geliştirilmiştir. 1985 yılında Aslı 
Baycan tarafindan Türkçe' ye çevrilmiştir. Biri 100 soruluk uzun ve diğeri de 20 soruluk kısa olmak üzere 2 ayrı formdan oluşmaktadır (Keser, 2006).

\section{Verilerin Analizi}

$\mathrm{Bu}$ araştırmanın bulguları SPSS analiz programı aracılı̆̆ıyla elde edilmiştir. Veriler yüzde ve frekans yöntemleriyle analiz edilmiştir. Uygulanan ölçeğin yapı geçerliliği, açıklayıcı faktör analizi sonucunda elde edilmiştir. Faktör analizi sonucu ulaşılan sonuçlara göre Cronbach's Alpha katsayısı göz önünde bulundurularak güvenirlilik analizi gerçekleştirilmiştir. Ölçek ve boyutları ilişkin dağılım normalliği Kolmogorov - Smirnov testi (normal dağılım analizi) ile analiz edilmiştir. Ardından değişkenler arasındaki ilişki durumunu belirtmek için korelasyon analizi gerçekleştirilmiş. Hipotezleri test etmek için hiyerarşik regresyon ve farklılık analizi yapılarak sonuçlar tablolar halinde sunulmuş ve değerlendirilmiştir. Çalışmada farklılık çözümlemelerinin neden-sonuç arasındaki bağ da incelenmiştir.

\section{E. Demografik Özellikler}

Tablo 1. Araştırmaya Katılan Kişilere Ait Demografik Özellikler

\begin{tabular}{|c|c|c|}
\hline Gruplar & Frekans & Yüzde \\
\hline \multicolumn{3}{|l|}{ Cinsiyet } \\
\hline Kadın & 66 & 23,1 \\
\hline Erkek & 220 & 76,9 \\
\hline \multicolumn{3}{|l|}{ Yaş } \\
\hline $18-30$ Yaş Arası & 46 & 16,1 \\
\hline 31 - 40 Yaş Arası & 157 & 54,9 \\
\hline 41 - 50 Yaş Arası & 71 & 24,8 \\
\hline 51 Yaş ve Üzeri & 12 & 4,2 \\
\hline \multicolumn{3}{|l|}{ Medeni Durum } \\
\hline Evli & 218 & 76,2 \\
\hline Bekar & 68 & 23,8 \\
\hline \multicolumn{3}{|l|}{ Eğitim Düzeyi } \\
\hline Lise & 21 & 7,3 \\
\hline Önlisans & 28 & 9,8 \\
\hline Lisans & 107 & 37,4 \\
\hline Yüksek Lisans & 40 & 14,0 \\
\hline Doktora & 90 & 31,5 \\
\hline \multicolumn{3}{|l|}{ Hizmet Süresi } \\
\hline 5 Y1l ve Alt1 & 45 & 15,7 \\
\hline $6-10$ Y11 Arası & 112 & 39,2 \\
\hline $11-15$ Y11 Aras 1 & 72 & 25,2 \\
\hline $16-20$ Y11 Aras1 & 27 & 9,4 \\
\hline 21 Yil ve Üzeri & 30 & 10,5 \\
\hline \multicolumn{3}{|l|}{ Hizmet Sinıfi } \\
\hline İdari Personel & 172 & 60,1 \\
\hline Akademik Personel & 114 & 39,9 \\
\hline
\end{tabular}

Araştırmaya katılan 286 kişiye ilişkin bulgular Tablo 1'de görülmektedir. Araştırmaya katılanların \%76,9'u erkek, \%23,1'i kadın; \%54,9'u 31 ile 40 yaş 
arasında; \%76,2'si evli; \%37,4'ü lisans mezunu; \%39,2'si 6 ile 10 y1l arasında çalışmış ve \%60,1'i idari personel olarak görev yapmıştır.

\section{F. Motivasyon Ölçeğine İlişkin Açıklayıcı Faktör Analizi}

$\mathrm{Bu}$ araştırmada uygulanan ölçeğin yapı geçerliliği durumunu, açıklayıcı faktör analizi ile değerlendirmeye alınmıştır. Etmen miktarının seçilmesinde çizgi grafiği, etmen öz kıymeti ve varyansa olan katk1 miktarı göz önünde bulundurulmuştur. Ölçeğin etmen desenini açığa çıkarmak amacıyla, faktörleştirme usulü olarak temel bileşenler çözümlemesi ve çevirme yönteminde ise dik çevirme yöntemlerinden varimax (maksimum) kullanılmıştır. Faktör yapısını belirlemek amacıyla, 286 kişinin ölçeğe verdiği cevaplar sonucunda elde edilen puanlara, temel bileşenler faktör analizi uygulanmıştır. Sonuçların faktör analizinde uygun olup olmadığının testi için, Kaiser - Meyer - Olkin (KMO) örneklem yeterliliği testi için ayrıca Bartlett küresellik testi kullanılmıştır.

Tablo 2. Motivasyon Ölçeği Açıklayıcı Faktör Analizi

\begin{tabular}{|c|c|c|c|}
\hline Faktörün Adı & Soru İfadesi & $\begin{array}{l}\text { Faktör } \\
\text { Yükü }\end{array}$ & \%'si $\quad$ Faktör \\
\hline \multirow{5}{*}{ Akademik Çevre Algısı } & Motivasyon 3 & 0,849 & \multirow{5}{*}{16,382} \\
\hline & Motivasyon 4 & 0,774 & \\
\hline & Motivasyon 1 & 0,763 & \\
\hline & Motivasyon 5 & 0,691 & \\
\hline & Motivasyon 2 & 0,615 & \\
\hline \multirow{6}{*}{ Mesleki Performans } & Motivasyon 14 & 0,745 & \multirow{6}{*}{14,172} \\
\hline & Motivasyon 11 & 0,733 & \\
\hline & Motivasyon 13 & 0,604 & \\
\hline & Motivasyon 15 & 0,595 & \\
\hline & Motivasyon 6 & 0,569 & \\
\hline & Motivasyon 12 & 0,549 & \\
\hline \multirow{4}{*}{ Mesleki Sorumluluk } & Motivasyon 22 & 0,822 & \multirow{4}{*}{14,045} \\
\hline & Motivasyon 21 & 0,766 & \\
\hline & Motivasyon 24 & 0,735 & \\
\hline & Motivasyon 25 & 0,675 & \\
\hline \multirow{4}{*}{ Kurumun Vizyonunu Benimseme } & Motivasyon 18 & 0,789 & \multirow{4}{*}{12,326} \\
\hline & Motivasyon 16 & 0,683 & \\
\hline & Motivasyon 17 & 0,609 & \\
\hline & Motivasyon 19 & 0,581 & \\
\hline \multirow{2}{*}{ Kişisel Gelişim } & Motivasyon 7 & 0,824 & \multirow{2}{*}{6,632} \\
\hline & Motivasyon 8 & 0,642 & \\
\hline \multirow{2}{*}{\multicolumn{3}{|c|}{$\begin{array}{rr}\text { Toplam } \\
\text { Kaiser - Meyer - Olkin Örneklem Yeterliliği }\end{array}$}} & 63,556 \\
\hline & & & 0,867 \\
\hline \multirow{2}{*}{\multicolumn{2}{|c|}{ Bartlett's Küresellik Testi }} & Ki Kare & 2787,952 \\
\hline & & p değeri & 0.000 \\
\hline
\end{tabular}

Ölçeğe ait KMO sonuç uygunluk sınırı olan 0,60'ın (Nakip, 2003), yukarısında 0,86 şeklinde saptanmış, KMO katsayısı veri sonuçlarının analize uygun sonuç verdiği göstermektedir. Bartlett testi de 0,50'nin yukarısında olduğu 

Aractlık Etkisi: Batman Üniversitesi Örneği

ve 0,05 önem değerinin anlam taşıdığ 1 veri seti faktör analizine uyumlu bulunmuştur.

Varyansı açıklama derecesi 0,50 ve yukarısında olması esas alınmıştır. Örneklem yeterliliği derecesi 0,50 oranını aşağısında kalan, faktör altında tek kalan ve faktör ağırlığı 0,50’nin aşağısında olan sorular analizde dikkate alınmamış, yapılan faktör analizinde öz değerleri 1 ve yukarısında olan 5 faktör elde edilmiştir. Bu faktörler sırasıyla; "akademik çevre algisı", "mesleki performans", "mesleki sorumluluk", "kurumun vizyonunu benimseme" ve "kişisel gelişim” olarak anlamlandırılmıştır. Toplam açıklanan varyans \%63,5 olarak bulunmuştur. Tablo 2'de ölçeğe ait faktör analizi sonuçlarını, faktör yüklerine göre büyükten küçüğe doğru sıralanmış bir halde göstermektedir.

\section{G. İş Tatmini Ölçeğine İlişkin Açıklayıcı Faktör Analizi}

Tablo 3. İş Tatmini Ölçeği Açıklayıcı Faktör Analizi

\begin{tabular}{|c|c|c|c|}
\hline Faktörün Adı & Soru İfadesi & $\begin{array}{l}\text { Faktör } \\
\text { Yükü }\end{array}$ & $\begin{array}{l}\text { Faktör } \\
\% \text { 'si }\end{array}$ \\
\hline \multirow{7}{*}{ İş Doyumu } & İş Tatmini 15 & 0,750 & \multirow{7}{*}{24,324} \\
\hline & İş Tatmini 16 & 0,710 & \\
\hline & İş Tatmini 14 & 0,701 & \\
\hline & İş Tatmini 20 & 0,640 & \\
\hline & İş Tatmini 13 & 0,637 & \\
\hline & İş Tatmini 11 & 0,631 & \\
\hline & İş Tatmini 10 & 0,562 & \\
\hline \multirow{3}{*}{ Yönetime Duyulan Güven } & İş Tatmini 5 & 0,834 & \multirow{3}{*}{15,239} \\
\hline & İş Tatmini 6 & 0,806 & \\
\hline & İş Tatmini 7 & 0,577 & \\
\hline \multirow{3}{*}{ İş Yeri Sadakati } & İş Tatmini 3 & 0,796 & \multirow{3}{*}{12,899} \\
\hline & İş Tatmini 4 & 0,596 & \\
\hline & İş Tatmini 2 & 0,556 & \\
\hline \multirow{3}{*}{ İş Yeri Memnuniyeti } & İş Tatmini 18 & 0,825 & \multirow{3}{*}{11,051} \\
\hline & İş Tatmini 1 & 0,652 & \\
\hline & İş Tatmini 17 & 0,570 & \\
\hline & \multirow{2}{*}{\multicolumn{2}{|c|}{$\begin{array}{rr}\text { Toplam } \\
\text { Kaiser - Meyer - Olkin Örneklem Yeterliliği } \\
\end{array}$}} & 63,513 \\
\hline & & & 0,916 \\
\hline & \multirow{2}{*}{ Bartlett's Küresellik Testi } & Ki Kare & 2020,972 \\
\hline & & $\mathrm{p}$ değeri & 0.000 \\
\hline
\end{tabular}

Ölçeğe ait KMO değeri 0,91 tespit edilmiş, elde edilen katsayı verilerin analize uygun olduğunu gözlenmektedir. Bartlett küresellik testi de 0,50'nin yukarısında olduğu ve 0,05 önem oranı anlam taşıdığından veri seti faktör analizine uygun derecede bulunmuştur. Varyansı açıklama derecesi 0,50 ve üzerinde olma ölçütü esas alınmıştır. Örneklem ölçüsü 0,50 derecesinin aşağısında kalan, faktör altında tek kalan ve faktör ağırlığ 10,50 'nin altında olan sorular analizden çıkarılmış ve yapılan faktör analizinde öz değerleri 1 ve üzerinde olan 4 faktör elde edilmiştir. Bu faktörler sırasılyla; “iş doyumu”, "yönetime duyulan güven”, “iş yeri sadakati” ve "iş yeri memnuniyeti” olarak isimlendirilmiş. Açıklanan varyans \%63,5 olarak tespit edilmiştir. Tablo 3, ölçeğe kısmına ait faktör analizi bulgularını, faktör 
yüklerine göre büyükten küçüğe doğru derecelendirilmiş bir durumda gösterilmiştir.

\section{H. Sosyal Sermaye Ölçeğine İlişkin Açıklayıcı Faktör Analizi}

Tablo 4. Sosyal Sermaye Ölçeği Açıklayıcı Faktör Analizi

\begin{tabular}{|c|c|c|c|}
\hline Faktörün Adı & Soru İfadesi & $\begin{array}{l}\text { Faktör } \\
\text { Yükü }\end{array}$ & $\begin{array}{l}\text { Faktör } \\
\% \text { 'si }\end{array}$ \\
\hline \multirow{4}{*}{ Kurum Kültürünü Benimseme } & $6 \quad$ Sosyal Sermaye & 0,889 & \multirow{4}{*}{43,667} \\
\hline & $7 \quad$ Sosyal Sermaye & 0,852 & \\
\hline & $5 \quad$ Sosyal Sermaye & 0,820 & \\
\hline & Sosyal Sermaye & 0,747 & \\
\hline \multirow{3}{*}{ Kurum İçinde Bilgi Paylaşımı } & Sosyal Sermaye & 0,928 & \multirow{3}{*}{36,038} \\
\hline & $\begin{array}{ll} & \text { Sosyal Sermaye }\end{array}$ & 0,910 & \\
\hline & Sosyal Sermaye & 0,763 & \\
\hline & & Toplam & 79,705 \\
\hline & \multicolumn{2}{|c|}{ Kaiser - Meyer - Olkin Örneklem Yeterliliği } & 0,834 \\
\hline & \multirow{2}{*}{ Bartlett's Küresellik Testi } & Ki Kare & 1446,173 \\
\hline & & p değeri & 0.000 \\
\hline
\end{tabular}

Ölçeğe ait KMO değeri 0,83 değerinde tespit yapılmış, elde edilen katsayı verilerin analize elverişliliğin göstermektedir. Bartlett küresellik testi de 0,50'nin yukarısında olduğu ve 0,05 önemlilik derecesinin bir anlam ifade ettiği, veri seti faktör analizine elverişli bulunmuştur. Varyansı açıklama tutarının 0,50 ve yukarısında olması ölçütü temel alınmıştır. Örneklem yeterliliği oranı 0,50 derecesinin altında kalan, faktör aşağısında tek kalan ve faktör derecesi 0,50'nin aşağısında olan sorular analizde dikkate alınmamış ve oluşturulan faktör analizinde öz değerleri 1 ve üzerinde olan 2 faktör elde edilmiştir. Bu ifadeler incelenerek, literatüre uyumlu olacak şekilde faktörler yazarlar tarafından "kurum kültürünü benimseme" ve "kurum içinde bilgi paylaşımı" şeklinde isimlendirilmiştir. Varyansın açılanan toplamı \%79,7 şeklinde bulunmuştur. Tablo 4, ölçeğe ait faktör analizi sonuçlarını, faktör yüklerine göre büyükten küçüğe doğru siralamasıyla göstermektedir.

\section{Güvenilirlik Analizi}

Faktör analizi sonucunda sınıflandırma biçimleri kesin olan sorular, ulaşılan sonuçlara göre birleştirilerek güvenilirlik analizine tabi tutulmuştur. Güvenilirlik analizlerinde, Cronbach's Alpha katsayısı göz önünde bulundurulmuştur.

Motivasyon ölçeğinin genel güvenilirlik katsayısının 0,902 ; iş tatmini ölçeğinin genel güvenilirlik katsayısı 0,906 ; sosyal sermaye ölçeğinin genel güvenilirlik katsayısının 0,898 şeklinde gözükmektedir. Analiz sonucunda elde edilen sonuçlar, literatürde öngörülen 0,60 düşük derece kriterini sağlamaktadır (Cronbach, 1990; Punch, 2005). Dolayısıyla elde edilen bu sonuçlar, çalışmada 
kullanılan ölçek ve boyutlarına ilişkin ifadelerin yüksek derecede tutarlılığ1 bulunduğu ortaya çıkarmaktadır.

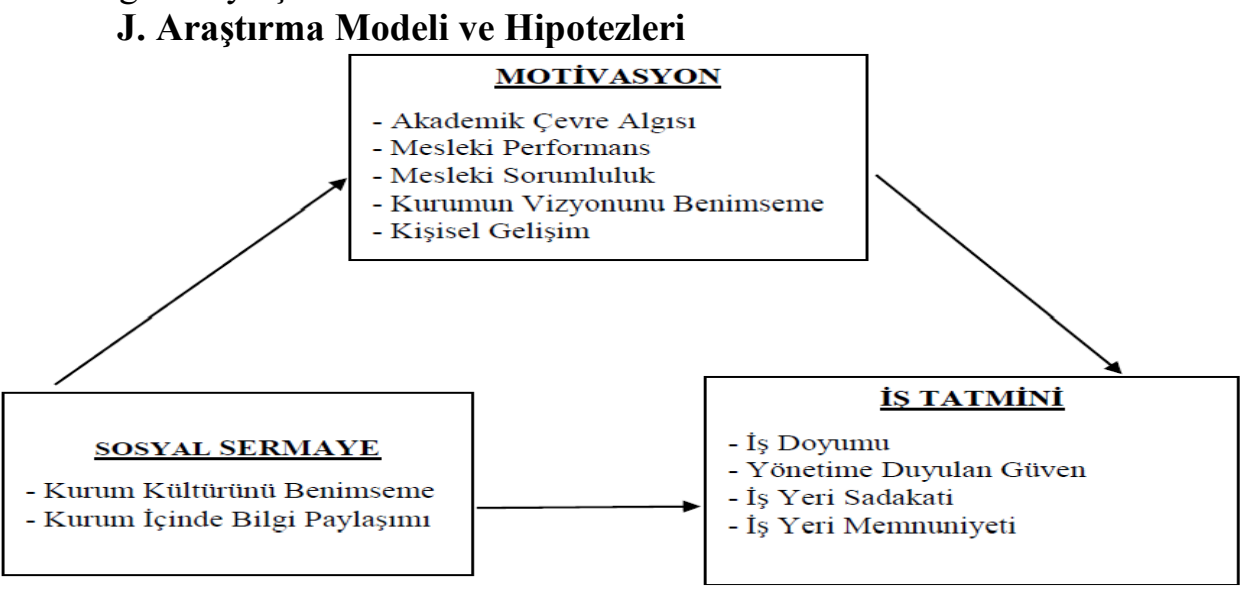

Şekil 1. Araştırmanın Ana Modeli

$\mathrm{H}_{1}$ : Sosyal sermaye ve çalışan motivasyonu arasında olumlu yönde ilişki vardır.

$\mathrm{H}_{2}$ : Motivasyon ve iş tatmini arasında olumlu yönde ilişki vardır.

$\mathrm{H}_{3}$ : Sosyal sermaye ve iş tatmini arasında olumlu yönde ilişki vardır.

$\mathrm{H}_{4}$ : Motivasyonun sosyal sermaye ve iş tatmini arasında ara değişken etkisine sahiptir.

$\mathrm{H}_{5}$ : Sosyal sermayenin motivasyon ve iş tatmini arasında ara değişken etkisine sahiptir.

$\mathrm{H}_{6}$ : İş tatmininin motivasyon ve sosyal sermaye arasında ara değişken etkisine sahiptir.

\section{K. Korelasyon Analizi}

Tablo 5'deki korelasyon analizi, çalışma değişkenleri arasındaki ilişkilerin durumu ve kuvvet derecesine ilişkin bilgi sunmaktadır.

Tablo 5. Korelasyon Analizi

\begin{tabular}{|c|c|c|c|c|c|c|c|c|c|c|c|c|c|c|c|c|}
\hline Değişkenler & Ort. & St. Sp. & 1. & 2. & 3. & 4. & 5. & 6. & 7. & 8. & 9. & 10. & 11. & 12. & 13. & 14. \\
\hline 2. F2M & 4,14 & 0,67 &, $392 * *$ & 1 & & & & & & & & & & & & \\
\hline 3. F3M & 4,21 & 0,74 &, $373^{* *}$ &, $440 * *$ & 1 & & & & & & & & & & & \\
\hline 4. $\mathrm{F} 4 \mathrm{M}$ & 3,71 & 0,77 & $.551^{* * *}$ & $422 * *$ & $373 * *$ & 1 & & & & & & & & & & \\
\hline 6. Motivasyon & 3,86 & 0,60 & $824^{* *}$ & $.708 * *$ & $621^{* *}$ & $.747^{* *}$ &, $592 * *$ & 1 & & & & & & & & \\
\hline 7. FiIT & 3.25 & 0.93 & $.620^{* * *}$ & $.379 * *$ & $.320^{* * *}$ & $.711^{* *}$ & $.349 * *$ & $.703 * *$ & 1 & & & & & & & \\
\hline 8. F2IT & 3,19 & 0,99 & $.408^{* *}$ & $.282 * *$ & $.234^{* *}$ & $.509 * *$ & $.231 * *$ & $.478^{* *}$ & $.634 * *$ & 1 & & & & & & \\
\hline 12. FIS & 3.27 & 0.96 & $.377 * *$ & $.322^{* *}$ & $.238^{* *}$ & $.457 * *$ & $.245^{* *}$ & $.467 * *$ & $.554 * *$ & $.473^{* *}$ & $.377 * *$ & $.334^{* *}$ & $.567 * *$ & 1 & & \\
\hline 13. F2S & 3,25 & 1,15 & $.385 * *$ &, $291^{* *}$ & $.260^{* *}$ & $.437 * *$ & $.161^{* *}$ & $.449 * *$ & $.592^{* *}$ & $.611^{* *}$ & $.477 * *$ &, $345^{* *}$ & $.648 * *$ & $.591^{* *}$ & 1 & \\
\hline 14. Sosyal Sermaye & 3,26 & 0,92 & $.427 * *$ & ,339** &, $265 * *$ &, $501^{* *}$ &, $226^{* *}$ &, $508^{* *}$ & ,635** & ,597** & ,462** &, $357^{* *}$ & $.668^{* *}$ &, $893 * *$ & ,879** & 1 \\
\hline
\end{tabular}


Tablodaki değişkenler, F1M (akademik çevre algısı), F2M (mesleki performans), F3M (mesleki sorumluluk), F4M (kurumun vizyonunu benimseme), F5M (kişisel gelişim), F1 İT (iş doyumu), F2İT (yönetime duyulan güven), F3 İT (iş yeri sadakati), F4İT (iş yeri memnuniyeti), F1S (kurum kültürünü benimseme), F2S (kurum içinde bilgi paylaşımı) şeklinde sınıflandırılmıştır.

Değişkenlerin ortalaması 3,19 ile 4,21; standart sapması ise 0,60 ile 1,15 arasında değişmektedir. Motivasyon $(\bar{X}=3,86)$; iş tatmini $(\bar{X}=3,37)$ ve sosyal sermaye $(\bar{X}=3,26)$ değişkenlerinin ortalaması orta seviyededir.

Sosyal sermaye ile motivasyon $(r=0,508)$ ve iş tatmini $(r=0,668)$ arasında 0,01 anlamlılık düzeyinde pozitif yönlü ilişki bulunmaktadır. Motivasyon ve iş tatmini $(r=0,743)$ arasında da 0,01 anlamlılık düzeyinde pozitif yönlü ilişki vardır.

\section{Hiyerarşik Regresyon Analizi}

H4: Motivasyonun, sosyal sermaye ve iş tatmini arasında ara değişken etkisine sahiptir.

$\mathrm{Bu}$ kapsamda, öncelikle bağımsız değişken (sosyal sermaye) ile aracılık etkisine sahip olduğu düşünülen değişken (motivasyon) arasında bir regresyon analizinin yapılması ve anlamlı bir ilişkinin olup-olmadığının belirlenmesi gereklidir. İkinci olarak, bağımsız değişken (sosyal sermaye) ile bağımlı değişken (iş tatmini) arasındaki neden sonuç ilişkisi araştırılmalıdır. Son olarak, aracı değişken (motivasyon) ile bağımlı değişkenin (iş tatmini) kontrol edildiği bir regresyon analizi yapılmalıdır. Bu analizler sonucunda, bir arac1lık etkisinin olupolmadığını ortaya koyabilmek için; ikinci aşamada bağımsız değişkenin (sosyal sermaye) bağımlı değişken (iş tatmini) üzerindeki etkisinin tamamen ortadan kalkıp kalkmadığına bakılmalıdır. Bu noktada, etkide bir düşme görülüyor ve ilişki anlamlılığını sürdürüyorsa, "kısmi aracılık etkisi”"nden; etki tamamen ortadan kalkıyorsa "tam aracılık etkisi”"nden söz edilebilir. Tablo 6, araştırma modeline ait hiyerarşik regresyon analizi verilerini vermektedir.

Tablo 6. $\mathrm{H}_{4}$ için Hiyerarşik Regresyon Analizi

\begin{tabular}{|c|c|c|c|c|c|}
\hline & $\begin{array}{c}\text { Standartlaştırılmamış } \\
\text { B }\end{array}$ & $\begin{array}{l}\text { Standartlasstırılmamış } \\
\text { Standart Hata }\end{array}$ & Std. $\beta$ & $\mathrm{F}$ & p Değeri \\
\hline $\begin{array}{l}\text { Model } 1 \\
\text { Sabit }\end{array}$ & 1,630 & ,122 & & \multirow{3}{*}{$119,292^{*}$} & ,000 \\
\hline $\begin{array}{l}\text { Kurum } \\
\text { Kültürünü } \\
\text { Benimseme }\end{array}$ & ,246 & ,042 &, 316 & & ,000 \\
\hline $\begin{array}{l}\text { Kurum İçinde } \\
\text { Bilgi Paylaşımı }\end{array}$ & ,289 & ,035 &, 444 & & ,000 \\
\hline $\begin{array}{l}\text { Model } 2 \\
\text { Sabit }\end{array}$ & ,080 & , 169 & & \multirow{5}{*}{$97,399^{*}$} & ,635 \\
\hline $\begin{array}{l}\text { Kurum } \\
\text { Kültürünü } \\
\text { Benimseme } \\
\end{array}$ & ,083 & ,033 & ,107 & & ,011 \\
\hline $\begin{array}{l}\text { Kurum İçinde } \\
\text { Bilgi Paylaşımı }\end{array}$ &, 175 & ,027 & ,269 & &, 000 \\
\hline $\begin{array}{l}\text { Akademik Çevre } \\
\text { Algısı }\end{array}$ & , 199 & ,032 &, 252 & & ,000 \\
\hline $\begin{array}{l}\text { Mesleki } \\
\text { Performans }\end{array}$ &,- 024 & ,048 &,- 022 & & ,616 \\
\hline
\end{tabular}


Muhammed Mahsun Şahin \& Osman Yılmaz / Sosyal Sermayenin Motivasyon ve İş Tatmini Arasındaki Aractlık Etkisi: Batman Üniversitesi Örneği

\begin{tabular}{|l|l|l|l|l|l|}
\hline $\begin{array}{l}\text { Mesleki } \\
\text { Sorumluluk }\end{array}$ &, 070 &, 041 &, 069 & &, 091 \\
\hline $\begin{array}{l}\text { Kurum } \\
\text { Vizyonunu } \\
\text { Benimseme }\end{array}$ &, 365 &, 042 &, 376 & & \multirow{2}{*}{000} \\
\hline Kişisel Gelişim &, 057 &, 031 &, 070 & &, 062 \\
\hline
\end{tabular}

$(\mathrm{n}=286)$ NOT: Model 1 için $\mathrm{R}^{2}=0,457(\mathrm{p}<0,05) ;$ Model 2 için $\Delta \mathrm{R}^{2}=0,253(\mathrm{p}<0,05) ;{ }^{*} \mathrm{p}<0,05$

Tablo 6'de temsil edilen ilk model; sadece sosyal sermaye ve boyutları ile iş tatmini arasındaki ilişkiyi; 2. model ise sosyal sermaye ve boyutları bağımsız değişkenlerinin, motivasyon ve boyutları ara değişkenleri olarak iş tatmini üzerindeki etkisini göstermektedir. İlk model varyansın \%45'ini açılarken; motivasyon ve boyutları eklendiğinde varyansın \%71'ini açıklamaktadır. Yani ara değişken olarak eklenen motivasyon ve boyutları varyansın toplam \%25'ini daha açıklamaktadır. İlk model 0,05 güven aralığında anlamlı olduğu görülmekte iken, ara değişkenler eklendiğinde model 2'nin 0,05 güven aralığında anlamlı olmadığ tespit edilmektedir.

Model 1 sonuçları incelendiğinde $\mathrm{H}_{1}, \mathrm{H}_{2}$ ve $\mathrm{H}_{3}$ hipotezleri desteklenmekte fakat; 2. modele göre $\mathrm{H}_{4}$ hipotezi desteklenmemektedir.

H5: Sosyal sermayenin motivasyon ve iş tatmini arasında ara değişken etkisine sahiptir.

Tablo 7. $\mathrm{H}_{5}$ için Hiyerarşik Regresyon Analizi

\begin{tabular}{|c|c|c|c|c|c|}
\hline & $\begin{array}{c}\text { Standartlaştırılmamış } \\
\text { B }\end{array}$ & $\begin{array}{l}\text { Standartlaştırılma } \\
\text { miș Standart Hata }\end{array}$ & Std. $\beta$ & F & p Değeri \\
\hline Model 1 Sabit &, 134 & , 190 & & \multirow{6}{*}{$95,136^{*}$} & ,009 \\
\hline Mesleki Performans & 320 & ,073 & 289 & & ,000 \\
\hline Mesleki Sorumluluk &, 115 & 056 &, 113 & & ,041 \\
\hline $\begin{array}{l}\text { Kurum Vizyonunu } \\
\text { Benimseme }\end{array}$ &, 259 & ,061 &, 266 & &, 000 \\
\hline Kişisel Gelişim &, 065 & ,039 & ,080 & &, 042 \\
\hline Motivasyon & 1,118 & ,147 & 892 & & ,000 \\
\hline Model 2 Sabit &, 080 & ,169 & & \multirow{8}{*}{$97,399 *$} & ,005 \\
\hline Mesleki Performans & ,263 &, 065 & 237 & &, 000 \\
\hline Mesleki Sorumluluk & 089 &, 050 & ,088 & &, 025 \\
\hline $\begin{array}{l}\text { Kurum Vizyonunu } \\
\text { Benimseme }\end{array}$ & ,206 & ,054 &, 212 & &, 000 \\
\hline Kişisel Gelişim & ,022 & ,035 & 027 & & ,023 \\
\hline Motivasyon & 836 & ,134 & ,668 & & ,000 \\
\hline $\begin{array}{l}\text { Kurum Kültürünü } \\
\text { Benimseme }\end{array}$ & ,083 & ,033 & ,107 & & ,011 \\
\hline $\begin{array}{l}\text { Kurum İçinde Bilgi } \\
\text { Paylaşımı }\end{array}$ &, 175 &, 027 &, 269 & &, 000 \\
\hline
\end{tabular}

$(\mathrm{n}=286)$ NOT: Model 1 için $\mathrm{R}^{2}=0,623(\mathrm{p}<0,05)$; Model 2 için $\Delta \mathrm{R}^{2}=0,181(\mathrm{p}<0,05) ; * \mathrm{p}<0,05$

Tablo 7'da temsil edilen ilk model; sadece motivasyon ve boyutları ile iş tatmini arasındaki ilişkiyi; 2. model ise motivasyon ve boyutları bağımsız değişkenlerinin, sosyal sermaye ve boyutları ara değişkenleri olarak iş tatmini üzerindeki etkisini göstermektedir. İlk model varyansın \%62'sini açıklarken; sosyal sermaye ve boyutları eklendiğinde varyansın \%80'ini açıklamaktadır. Yani ara 
değişken olarak eklenen sosyal sermaye ve boyutları varyansın toplam \%18'ini daha açıklamaktadır. Kurulan model 0,05 güven aralığında anlamlıdır.

Analiz sonuçlarına göre; motivasyon ve boyutları ile iş tatmini arasında istatistiki bir ilişki bulunmaktadır $(p<0,05)$. Model 2'ye göre motivasyonun iş tatmini üzerindeki etkisi azalarak devam etmiştir. Aynı zamanda sosyal sermayenin motivasyon ve iş tatmini arasında ilişkisi bulunmaktadır. Bu nedenle, sosyal sermaye, motivasyon ve iş tatmini arasında kısmi ara değişken etkisine sahiptir. Bu sonuçlara göre; $\mathrm{H}_{5}$ hipotezi desteklenmektedir.

$\mathbf{H}_{\mathbf{6}}$ : İş tatmini, motivasyon ve sosyal sermaye arasında ara değişken etkisine sahiptir.

Tablo 8. $\mathrm{H}_{6}$ için Hiyerarşik Regresyon Analizi

\begin{tabular}{|c|c|c|c|c|c|}
\hline & $\begin{array}{c}\text { Standartlaştırılmamış } \\
\beta\end{array}$ & $\begin{array}{l}\text { Standartlaştırılma } \\
\text { mış Standart Hata }\end{array}$ & Std. $\beta$ & $\mathrm{F}$ & p Değeri \\
\hline Model 1 Sabit &, 284 &, 316 & & \multirow{6}{*}{$26,986^{*}$} &, 000 \\
\hline Mesleki Performans &, 180 &, 122 & 132 & &, 000 \\
\hline Mesleki Sorumluluk &, 101 & ,093 & ,081 & & ,007 \\
\hline $\begin{array}{l}\text { Kurum Vizyonunu } \\
\text { Benimseme }\end{array}$ &, 215 & ,101 & , 179 & & ,034 \\
\hline Kişisel Gelişim &, 128 & ,064 &, 127 & &, 047 \\
\hline Motivasyon & ,984 & ,245 & ,636 & & ,000 \\
\hline Model 2 Sabit &, 221 &, 282 & & \multirow{10}{*}{$29,635^{*}$} &, 004 \\
\hline Mesleki Performans &, 034 &, 115 & ,025 & & ,008 \\
\hline Mesleki Sorumluluk &, 023 & ,088 & ,018 & & ,006 \\
\hline $\begin{array}{l}\text { Kurum Vizyonunu } \\
\text { Benimseme }\end{array}$ & ,002 & ,092 & ,001 & & ,006 \\
\hline Kişisel Gelişim &, 087 & ,057 & ,086 & & ,008 \\
\hline Motivasyon &, 324 & ,242 &, 210 & &, 002 \\
\hline İş Doyumu & ,288 & ,078 & ,288 & & ,000 \\
\hline $\begin{array}{l}\text { Yönetime Duyulan } \\
\text { Güven }\end{array}$ & ,318 &, 054 & ,339 & &, 000 \\
\hline İş Yeri Sadakati & 025 & ,064 & ,023 & & ,008 \\
\hline İş Yeri Memnuniyeti &, 045 & 070 & 039 & & 009 \\
\hline
\end{tabular}

$(\mathrm{n}=286)$ NOT: Model 1 için $\mathrm{R}^{2}=0,325(\mathrm{p}<0,05)$; Model 2 için $\Delta \mathrm{R}^{2}=0,166(\mathrm{p}<0,05) ;{ }^{*} \mathrm{p}<0,05$

Tablo 8'de temsil edilen ilk model; sadece motivasyon ve boyutları ile sosyal sermaye arasındaki ilişkiyi; 2 . model ise motivasyon ve boyutları bağımsız değişkenlerinin, iş tatmini ve boyutları ara değişkenleri olarak sosyal sermaye üzerindeki etkisini göstermektedir. İlk model varyansın \%32'sini açıklarken; iş tatmini ve boyutları eklendiğinde varyansın \%49'unu açıklamaktadır. Yani ara değişken olarak eklenen iş tatmini ve boyutları varyansın toplam \%16'sını daha açıklamaktadır. Kurulan model 0,05 güven aralığında anlamlıdır.

Analiz sonuçlarına göre; motivasyon ve boyutları ile sosyal sermaye arasında istatistiki bir ilişki bulunmaktadır $(p<0,05)$. Model 2'ye göre motivasyonun sosyal sermaye üzerindeki etkisi azalarak devam etmiştir. Aynı zamanda iş tatmini, motivasyon ve sosyal sermaye arasında ilişkisi bulunmaktadır. $\mathrm{Bu}$ nedenle, iş tatmini, motivasyon ve sosyal sermaye arasında kısmi ara değişken etkisine sahiptir. Bu sonuçlara göre; $\mathrm{H}_{6}$ hipotezi desteklenmektedir. 


\section{SONUÇ}

İşörenler olmadan işletmelerin başarılı olması mümkün değildir (Sabuncuoğlu ve Tokol, 2009). Sosyal bir varlık olan insanın, iş hayatında yaşadığ 1 olumlu etkileşim, işgörenlerin işyerine bağ l1lı̆ 1 , tatmini, huzuru, huzursuzluğu ve motivasyonu iş hayatını etkiler (Yazıcıoğlu, 2010). Örgütsel başarı için işinde tatmin olan, motive ve örgütü ile sosyal olarak özdeşleşmiş işgörenlere ihtiyaç vardır (Turunç ve Çelik, 2010).

Bu hususların önemine binaen çalışmada sosyal sermayenin motivasyon ve iş tatmini arasındaki aracılık etkisi Batman Üniversitesinde görevli akademik ve idari personel aracılığıyla ölçülmüş ve üniversitedeki 286 akademik ve idari personelden elde edilen veriler ile yapilan korelasyon analiz test sonucunda sosyal sermaye ile motivasyon, motivasyon ile iş tatmini ve sosyal sermaye ile iş tatmini arasında 0,01 anlamlılık düzeyinde pozitif yönde bir ilişki saptanmıştır.

Ayrıca hiyerarşik regresyon analiz test sonucunda sosyal sermayenin motivasyon ve iş tatmini arasında kısmi ara değişken etkisine sahiptir. Ara değişken sosyal sermaye ve boyutları varyansın toplam \%18'ini açılamaktadır ve model güven aralığında anlamlıdır. Analiz sonuçlarına göre; motivasyon ve boyutları ile iş tatmini arasında istatistiki bir ilişki bulunmuştur $(p<0,05)$. Bu çalışmanın hipotezi $\left(\mathrm{H}_{5}\right)$ kabul edilmiştir. Sosyal sermaye ve boyutları ile iş tatmini arasındaki ilişki varyansın \%45'ini açıklar. Bağımsız değişkenler, motivasyon ve boyutları ara değişkenleri olarak iş tatminini üzerindeki etkisi eklendiğinde varyansın \%71'ini açıklar. İlk model 0,05 aralığında olduğundan pozitif yönlü ilişki tespit edilmiş ve bu sonuçlara göre $\left(\mathrm{H}_{1}\right),\left(\mathrm{H}_{2}\right)$ ve $\left(\mathrm{H}_{3}\right)$ hipotezi desteklenmektedir. İş tatminin, motivasyon ve sosyal sermaye arasında ara değişken etkisi varyansın \%16'sını açıklamaktadır. İş tatminin, motivasyon ve sosyal sermaye arasında ilişkisi bulunmaktadır. Aynı zamanda iș tatminin ara değișken etkisine sahip olduğu tespit edilmiştir. Bu sonuçlara göre $\left(\mathrm{H}_{6}\right)$ hipotezi desteklenmektedir.

$\mathrm{Bu}$ sonuçlara göre sosyal sermaye, bir örgütün işgörenleri arasındaki münasebeti belirleyen, işgörenlerin iş tatmini ve motivasyonu üzerinde etkisi olan bir kavramdır. Bu bulgular aşağıdaki örneklerde görüleceği üzere literatürdeki bulgular ile benzer yöndedir.

Sosyal sermaye örgütün başarısını doğrudan etkiler (Collins ve Clark, 2003; Subramaniam ve Youndt, 2005; Reed, Srinivasan ve Doty, 2009). İşgörenlerin ilişkisel bağlamı olan özdeşleşme sosyal sermayenin boyutlarından biridir ve çalışanlar için motivasyon kaynaklarındandır (Nahapiet ve Ghoshal, 1998). Motivasyon ve motivasyon araçları, çalışanların iş tatmine olumlu katkılar sağlar (Alsat, 2016).

Özmen, Aküzüm, Koçoğlu, Tan ve Demirkol (2014) ile tarafindan yapılan araştırmalarda sosyal sermayenin iş tatminini anlamlı olarak etkilediği, Akan ve Er Ülker (2015) akademik personelin iş tatmini düzeyleri, sosyal sermaye düzeyinden olumlu yönde etkilendiği sonucuna ulaşılmıştır.

$\mathrm{Bu}$ bağlamda "sürdürülebilir" bölgesel veya küresel ölçekte yükseköğretim kurumları, her alanda rakipleriyle rekabet edebilmesi için akademik kurumların insan faktörünü göz önünde bulundurması gerekmektedir. 
Tüm veriler 1şı̆̆ında iş tatmininin artması ve motivasyon arasında pozitif yönlü kuvvetli bir ilişki vardır. Cinsiyet, yaş, iş tecrübesi, medeni durum, eğitim seviyesi bu süreçleri etkileyen yapısal etmenler olmakla birlikte çalışılan iş yerindeki yöneticilerin tutumları, birlikte iş yapma yetisi, ortak imkanlar yaratabilme, sonuç odaklı yapılacak grup çalışmaları iş motivasyonunu yükseltecek ve mesleki tatmin sağlanacaktır.

$\mathrm{Bu}$ çalışmanın evrenini Batman üniversitesinde görevli akademik ve idari personeller oluşturmaktadır. Akademik kurumun ve işyerinin kendine özel koşulları olmasından hareketle ilgili örneklemin genelleme yapılamayacak olması çalışmanın sınırlılığını oluşturmaktadır.

\section{KAYNAKÇA}

Akan, B. ve Er Ülker, F. (2015). Sosyal Sermayenin İş Tatminine Olan Etkisi: Namık Kemal Üniversitesi Örneği, 1 st International Congrees on Applied Sciences: Social Copital, OCT 23-24, Konya/TURKEY.

Akıncı, Z. (2002). Turizm Sektöründe İş Gören Tatminini Etkileyen Faktörler: Beş Yıldızlı Konaklama İşletmelerinde Bir Uygulama, Akdeniz İ.I.B.F. Dergisi, Sayı:4. s.1-25.

Aksoy, B., Koçancı, M. ve Namal, M. K. (2019). Girişimcilik Motivasyonu: Uygulamalı Girişimcilik Eğitimi Katılımc1ları Örneği, Celal Beyar I.I.B.F. Yönetim ve Ekonomi Dergisi, 26(1), s.113.

Alsat, O. Ç. (2016). Çalışan Motivasyonunu Etkileyen Faktörlerin $\dot{I}_{S ̧}$ Tatminine Etkisini Belirlenmesine Yönelik Bir Uygulama (Doctoral Dissertation, Selçuk Üniversitesi Sosyal Bilimler Enstitüsü).

Armstrong, M. (2003). Handbook Of Human Resource Management Practice: Fully Updated To Reflect Current Thinking Practiceand Research. London: KoganPagePublish, s.221.

Baysal, A.C., Tekarslan, E. (1996). Davranış Bilimleri. 2. Bası. İstanbul: İstanbul Üniversitesi Yayınları.

Brislin, R. W., Kabigting, F., Macnab, B., Zukis, B. ve Worthley, R. (2005). Evolving Perceptions Of Japanese Wworkplace Motivation. International Journal of Cross Cultural Management. 5(1), 87-103.

Clugston, M., Howell, J. P. ve Dorfman, P. W. (2000). Does Cultural Socialization Predict Multiple Bases and Foci of Commitment?. Journal of Management. Vol: 26 (1). s.5-30.

Collins, C. J. ve Clark, K. D. (2003). Strategic Human Resource Practices, Top Management Team Social Networks and Firm Performance: The Role of Human Resource Practices in Creating Organizational Competitive Advantage. Academy of Management Journal 46 (6), 740-751.

Cronbach, L J. (1990). Essentials of Psychological Testing. Fifth Ed., New York: Harper Collins.

Çelik, P. (2010). Işs Görenlerin Motivasyon Düzeyleri ile Işs Tatmini ve İşe Devam İlişkisi Üzerine Turizm Sektöründe Bir Uygulama. Akdeniz Üniversitesi, Sosyal Bilimler Enstitüsü, Yüksek Lisans Tezi; Antalya.

Çetin, M. (2006). Endüstriyel Bölgelerde Sosyal Sermaye ve Güven: Üçüncü İtalya Örneği. Ege Akademik Bakış Dergisi, Cilt 6, Sayı:1, s.74-86.

Doğan, S. ve Aslan, M. (2018) Psikolojik Sermaye, İçsel Motivasyon ve İş Tatmini İlişkisi. Niğde Ömer Halisdemir Üniversitesi IIBFF Dergisi, Sayı: 11(3), s.112-125.

Durkan Şimşek, R. (2013). Illkokul ve Ortaokullardaki Sosyal Sermaye Düzeyi ile Öğretmenlerin Işs Doyumları Arasındaki İlişkinin İncelenmesi, Okan Üniversitesi, Sosyal Bilimler Enstitüsü, Yüksek Lisans Tezi: İzmir.

Dündar, S., Özutku, H., ve Taşpınar, F. (2007). İçsel ve Dışsal Motivasyon Araçlarının İşgörenlerin Motivasyonu Üzerindeki Etkisi: Ampirik Bir İnceleme. Gazi Üniversitesi Ticaret ve Turizm Eğitim Fakültesi Dergisi, (2), 105-119.

Düren, A.Z. (2002). 2000'li Yillarda Yönetim. İstanbul: Alfa Yayınları. 
Muhammed Mahsun Şahin \& Osman Yılmaz / Sosyal Sermayenin Motivasyon ve İş Tatmini Arasındaki Aracllık Etkisi: Batman Üniversitesi Örneği

Eryılmaz, İ. ve Altın Gülova, A. (2019) Örgüt Kültürü ve Bağlamsal Performans Arasındaki İlişkide Temel Motivasyon Kaynaklarının Biçimleyici Rolü. Celal Beyar I.I.B.F. Yönetim ve Ekonomi Dergisi, 26(2), s.499.

Field, J. (2008). Sosyal Sermaye (Çev. B. Bilgen, B. Şen), İstanbul Bilgi Üniversitesi Yayınları, İstanbul.

Gül, H., Ercan, O. ve Gökçe, H. (2008). İş Tatmini, Stres, Örgütsel Bağl1lık, İşten Ayrılma Niyeti ve Performans Arasındaki İlişkiler: Sağlık Sektöründe Bir Uygulama. Akademik Bakış Uluslar Arası Hakemli Sosyal Bilimler Dergisi, Sayı: 15, Ekim. s.1-11.

Güney, S. (2001). Yönetim ve Organizasyon. Ankara: Nobel Yayın Dağıtım.

Harpham, T., Grant, E., ve Thomas, E. (2002). Measuring Social Capital within Health Surveys: Key Issues. Health Policy Plan. 17, s.106-11.

Hodgetts, R. M. (1999). Yönetim: Teori, Süreç ve Uygulama. Çeviren: Canan Çetin ve Esin Can Mutlu. 2. Baskı. İstanbul: Der Yayınları.

Ingersoll, B. (2012). Brief report: Effect of a Focused Imitation Intervention On Social Functioning İn Children With Autism. Journal and of Autism Developmental Disorders, 42(8), s.17681773.

Jahangır, F. ve Shokrpour, N. (2009). Three Components of Organizational Commitment and Job Satisfaction of Hospital Nurses in Iran. The Health Care Manager, Volume 28, Number 4, pp. s.375-380.

Karcıoğlu, F. ve Timuroğlu, K. \& Çınar, O. (2009). Örgütsel İletişim ve İş Tatmini İlişkisi: Bir Uygulama. Yönetim Dergisi, Say1: 63 (20). s.59-76.

Keser, A. (2006) Çalışma Yaşamında Motivasyon. İstanbul: Alfa Aktüel Yayınları.

Koçel, T. (2018). Isşletme Yöneticiliği. İstanbul: Beta Yayınları.

Kouvonen, A., Oksanen, T., Vahtera, J., Stafford, M., Wilkinson, R., Schneider, J., Vaananen, A., Virtanen, M., Cox, S.J., Pentti, J., Elovainio, M., ve Kivimaki, M. (2008). Low Workplace Social Capital as a Predictor of Depression: The Finnish Public Sector Study, American Joumal of Epidemiolojy, Vol:167 No.10, s.1443-1151.

Lee, O. ve Tan, J. A. (2010). Goal Orientation And Organizational Commitment: Individual Difference Predictors of Job Perfformance. International Journal of Organizational Analysis, Vol:18, No.1, s.129-150.

Mahaney, C. R, ve Lederer, A. L. (2006). The Effect of Intrinsic and Extrinsic Rewards for Developers on Information Systems Project Success. Proj. Manage. J., 37: 42-54.

Mottaz, J. C. (1985). The Relative İmportance of Intrinsic and Extrinsic Rewards as Determinants of Wok Satisfaction. The Sociological Quarterly. 26(3), 365-385.

Nahapiet, J. ve Ghoshal, S. (1998). Social Capital, Intellectual Capital and the Organizational Advantage. The Academy of Management Review, 23 (2), 242-266.

Nakip, M. (2003). Pazarlama Araştırmaları Teknikler ve (SPSS Destekli) Uygulamalar. Ankara: Seçkin Yayıncılık.

Narayan, D. ve Woolcock, M. (2000). Social Capital: Implications for Development Theory, Research, and Policy. The World Bank Research Observer, 225-249.

Ören, K. (2007). Sosyal Sermayede "Güven” Unsuru ve İşgücü Performansına Etkisi. Kamu-İş Dergisi, Cilt 9, Say1 1. s.71-90.

Özdemir, A. A. (2008). Çalışanların İş Tatminlerinin Araştırılmasında Örgütsel Sosyal Sermaye Yeni Bir Belirleyici Olabilir Mi?, Yönetim Bilimleri Dergisi, (6:1).

Özmen, F., Aküzüm, C., Koçoğlu, E., Tan, Ç. ve Demirkol, M. (2014). Eğitim Kurumlarında Sosyal Sermayenin İş Tatmini Üzerindeki Etkisi, AKEV Akademi Dergisi, Sayı,58, s.333-345.

Prakash, S. ve Selle, P. (2004). Investigating Social Capital: Comparative Perspectives on Sivil Society, Participation and Governance: New Delhi \& Thousand Oaks, London. Sage Punlications.

Punch, K. (2005). Introduction to Social Research - Ouantitive and Oualitive Approach. Second Ed., Sage Publications Inc., California.

Putnam, R. (2000). Bowling Alone: The Collapse and Revival of American Community, New York: Simonn and Schuster. 
Reed, K. K., Srinivasan, N. ve Doty, D. H. (2009). Adapting Human and Social Capital to Impact Performance: Some Empirical Findings from theU.S. Personal Banking Sector. Journal of Managerial Issues, 21(1), 36-57

Sabuncuoğlu, Z. ve Tüz, M. (2005). Örgütsel Psikoloji. Bursa: Alfa Aktüel Basım Yayın.

Tocqueville, A. D. (1994). Amerika'da Demokrasi. Çeviren: İhsan Sezal ve Fatoş Dilber. Ankara: Yetkin Yayınları.

Subramaniam, M. ve Youndt, M. A. (2005). The Influence of Intellectual Capital on the Types of Innovative Capabilities. Academy of Management Journal 48 (3), 450-463.

Turunç, Ö., \& Çelık, M. (2010). Çalışanların algıladıkları örgütsel destek ve iş stresinin örgütsel özdeşleşme ve iş performansına etkisi. Journal of Management \& Economics, 17(2).

Yang, F. ve Chang, C. (2008). Emotional Labour, Job Satisfaction And Organizational Commitment Among Clinical Nurses: A Ouestionnaire Survey. International Journal of Nursing Studies, 45, s.879-887.

Yazıcıoğlu, İ. (2010). Örgütlerde İş Tatmini ve İş Gören Performansı İlişkisi: Türkiye ve Kazakistan Karşılaştırması. Bilig Dergisi, Sayı: 55. s.243-264.

\section{SUMMARY}

As a social entity, positive and negative impacts on business life affect working performance. Contemporary societies are now interacting with each other through communication networks. This interaction increases the level of satisfaction that individuals behave more consciously and in business life. Employees' satisfaction with their jobs is an indication that they are satisfied with the organization they work for. It is a fact that the satisfaction of the employees in their jobs will affect the service quality and efficiency provided in the institution. Employees want to perform their duties in line with their skills while performing their duties. They see themselves as part of the organization and adopt the institution they work for. As a result, motivation and job satisfaction levels increase.

In this study; The aim of the study was to investigate the mediation effect of motivation, social capital and job satisfaction of academic and administrative staff working at Batman University. 300 questionnaires were distributed by hand. In addition, an online questionnaire was sent to 750 personnel via e-mail. As a result of the two-week survey, 286 survey information were evaluated. As a result of the correlation analysis test, a positive correlation was found between social capital and motivation, motivation and job satisfaction, and social capital and job satisfaction at a significance level of 0.01 . In addition, the hierarchical regression analysis test determined this positive relationship and found that the first three (3) hitoptics were supported. As a result of the three-stage regression analysis, it was found that social capital had a partial inter-variable effect between motivation and job satisfaction, as well as job satisfaction.

In order to increase the productivity, productivity and loyalty of the job, the merits of academic and administrative promotions should be taken into consideration, and academic studies should be based on service regardless of unit and person differences. Administrative staff should be allowed to achieve their career development goals. Social organizations should be focused on in order to develop a sense of belonging in the institution. Taking the suggestions of the employees into consideration in the decisions taken about the institution is 

Aracllık Etkisi: Batman Üniversitesi Örneği

important for the corporate culture. Because social capital is the willingness and willingness of individuals to act collectively by increasing collective activities. In this case, people can support each other more. As a result of these effects of social factors, the accumulation of social capital will have a positive effect on the realization of the objectives of the organizations. Promotions have constructive effects on the employee. Some employers endure challenging and negotiating jobs that will benefit them, and the results that bring them to their work, and adhere to the wishes of their superiors. 